\title{
A Simple Theory of International Trade with Multinational Corporations
}

\section{Citation}

Helpman, Elhanan. 1984. A simple theory of international trade with multinational corporations. Journal of Political Economy 92(3): 451-471.

\section{Published Version}

doi:10.1086/261236

\section{Permanent link}

http://nrs.harvard.edu/urn-3:HUL.InstRepos:3445092

\section{Terms of Use}

This article was downloaded from Harvard University's DASH repository, and is made available under the terms and conditions applicable to Other Posted Material, as set forth at http:// nrs.harvard.edu/urn-3:HUL.InstRepos:dash.current.terms-of-use\#LAA

\section{Share Your Story}

The Harvard community has made this article openly available.

Please share how this access benefits you. Submit a story.

Accessibility 


\title{
| CHICAgo JOURNALS
}

\author{
A Simple Theory of International Trade with Multinational Corporations \\ Author(s): Elhanan Helpman \\ Source: The Journal of Political Economy, Vol. 92, No. 3 (Jun., 1984), pp. 451-471 \\ Published by: The University of Chicago Press \\ Stable URL: http://www.jstor.org/stable/1837227
}

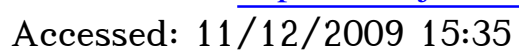

Your use of the JSTOR archive indicates your acceptance of JSTOR's Terms and Conditions of Use, available at http://www.jstor.org/page/info/about/policies/terms.jsp. JSTOR's Terms and Conditions of Use provides, in part, that unless you have obtained prior permission, you may not download an entire issue of a journal or multiple copies of articles, and you may use content in the JSTOR archive only for your personal, non-commercial use.

Please contact the publisher regarding any further use of this work. Publisher contact information may be obtained at http://www.jstor.org/action/showPublisher?publisherCode=ucpress.

Each copy of any part of a JSTOR transmission must contain the same copyright notice that appears on the screen or printed page of such transmission.

JSTOR is a not-for-profit service that helps scholars, researchers, and students discover, use, and build upon a wide range of content in a trusted digital archive. We use information technology and tools to increase productivity and facilitate new forms of scholarship. For more information about JSTOR, please contact support@jstor.org.

The University of Chicago Press is collaborating with JSTOR to digitize, preserve and extend access to The Journal of Political Economy. 


\title{
A Simple Theory of International Trade with Multinational Corporations
}

\section{Elhanan Helpman}

Tel-Aviv University and Massachusetts Institute of Technology

\begin{abstract}
Using the idea that firm-specific assets associated with marketing, management, and product-specific $\mathrm{R} \& \mathrm{D}$ can be used to service production plants in countries other than the country in which these inputs are employed, I develop a simple general equilibrium model of international trade in which the location of plants in a differentiated product industry is a decision variable. The model is then used to derive predictions of trade patterns, volumes of trade, the share of intra-industry trade, and the share of intrafirm trade as functions of relative country size and differences in relative factor endowments.
\end{abstract}

\section{Introduction}

The role of multinational corporations in the conduct of foreign trade has grown over time and has reached very large proportions. In the United States, for example, at the all-manufacturing level, multinational corporations accounted in 1970 for 62 percent of its exports ( $\$ 22$ billion out of $\$ 35$ billion) and 34 percent of its imports $(\$ 10.5$ billion out of $\$ 31$ billion) (see U.S. Tariff Commission 1973, p. 322). It is therefore not surprising that the ramifications of their existence

I wish to thank Richard Caves for insightful discussions during my work on this project, as well as my wife Ruth for patiently listening to long lectures on the subject of this paper. Helpful comments on a previous version were provided by Eitan Berglas, Torsten Persson, Lars Svensson, and José Scheinkman. This is a revised and much simplified version of Harvard Institute of Economic Research Discussion Paper no. 961. The first version was written when I was a Visiting Professor in the Department of Economics at Harvard University. 
are of major concern to international trade experts. Nevertheless, there exists no well-articulated theory that explains the conditions for their emergence or predicts under these conditions a structure of trade that comes close to observed trade patterns.

Existing general equilibrium theories of international trade have been developed without explicit treatment of the multinational corporation. The discussion of direct foreign investment in Caves (1971) (and the work that followed from it) is an exception. There are many treatments of the multinational corporation in a partial equilibrium framework (see Caves 1982, chap. 2), but they shed only limited light on a central problem of trade theory, namely, the explanation of trade patterns. We are in need of a theory that describes conditions under which firms find it desirable to shift activities to foreign locations and that is able to predict the pattern of trade that emerges under these conditions. Foundations of such a theory are proposed in this paper, with the following important features: $(a)$ there are differentiated products, economies of scale, and monopolistic competition; and $(b)$ there exist inputs (e.g., management, marketing, and R \& D) that can serve product lines without being located in their plants.

In this paper the theory deals with single product firms. I deal with horizontal and vertical integration in Helpman (1983b). Firms maximize profits and make, therefore, cost-minimizing location choices of product lines. This feature brings about the emergence of multinational corporations as a result of the tendency of factor rewards to differ across countries. Here the emphasis is on one source of pressure on relative factor rewards-differences in relative factor endowments. Transport costs and tariffs are assumed away, so that production facilities are not established in order to save transport costs or in order to produce behind tariff walls. Other reasons for multinationality, such as tax advantages of various forms, are also not considered.

Apart from describing in a general equilibrium system conditions under which firms choose to become multinational, the theory provides an explanation of trade patterns in which the multinational corporations play a central role. There is intersectoral, intra-industry, and intrafirm trade. The last trade component has become of major importance in recent years (see U.S. Tariff Commission 1973, chap. 3; Buckley and Pearce 1979).

In order to bring out as clearly as possible the value added of the theory, simplifying assumptions are used throughout. The next section provides a description of the basic model. The structure of an equilibrium in an integrated world economy is described in Section III. Then, in Section IV, the features of the integrated world equilibrium are used in order to describe the relationship between factor endowments and trade patterns. The behavior of the volume of trade 
is analyzed in Section $\mathrm{V}$ and the behavior of the shares of intraindustry and intrafirm trade is analyzed in Section VI. The last section is devoted to concluding remarks.

\section{The Basic Model}

For the purpose of the current study I employ a two-sector modified version of the now standard model of international trade in differentiated products. Preferences are assumed to be identical everywhere and representable by a homothetic utility function $u\left(Y, U_{x}\right)$, where $Y$ is the consumption level of a homogeneous product and $U_{x}=u_{x}(\cdot)$ is the subutility level attained in the consumption of differentiated products. The function $u_{x}(\cdot)$ depends on the specification of preferences for a differentiated product; they can be, for example, of the Dixit and Stiglitz (1977) type or of the Lancaster (1979) type (see Helpman [1983a, sec. 8] for a description). In both cases a demand function facing a producer of a single variety can be derived; in the Dixit-Stiglitz case this demand function is of the constant elasticity type (assumed to be larger than one), while in the Lancaster case its elasticity depends on commodity prices and the number of varieties available to consumers (and this elasticity is always larger than one).

It is assumed that there are two factors of production: labor, $L$, and a general purpose input, $H$, whose special role in the production of differentiated products will be explained below. The homogeneous product is produced by means of a standard linear homogeneous production function with the associated unit cost function $c_{Y}\left(w_{L}, w_{H}\right)$, where $w_{i}$ is the reward to factor $i$. A producer of the homogeneous product has to employ all inputs in the same location. In a competitive equilibrium the price of the homogeneous product, taken to be the numeraire, equals unit costs:

$$
1=c_{Y}\left(w_{L}, w_{H}\right) .
$$

The structure of production of differentiated products is more complicated. A firm that wants to produce a given variety has to hire the general purpose input $H$ and adapt it at a cost in order to make it suitable for the production of this variety. Once adapted, the input becomes a firm-specific asset in the sense used by Williamson (1981), and it is tied to the entrepreneurial unit. However, this firm-specific input can serve many plants and it need not be located within a plant in order to serve its product line. In particular, it can serve plants that are located in different countries (see Hirsch [1976] for a similar assumption). Inputs that fit this description are management, distribution, and product-specific $\mathrm{R} \& \mathrm{D}$. The importance of this type of asset in the operation of multinational corporations is described in 
Caves (1982, chap. 1). Clearly, in practice, combinations of inputs are required in order to generate such assets; here this aspect is simplified by assuming that only $H$ can serve this purpose.

Let $l\left(x, h_{X}\right)$ be the quantity of labor required to produce $x$ units of a variety of the differentiated product in a single plant when $h_{X}$ units of $H$ have been adapted for its particular use. A possible form for this function is $l=f_{p}+g_{1}\left(x, h_{X}\right)$, where $f_{p}>0$ and $g_{1}(\cdot)$ is positively linear homogeneous. Here $f_{p}$ generates a plant-specific fixed cost and the variable cost component exhibits constant returns to scale. More generally, I assume that $l(\cdot)$ is the inverse of an increasing-returns-to-scale production function in which $h_{X}$ is essential for production. Let also $g\left(w_{L}, w_{H}, h_{X}\right)$ be the minimum costs required in order to adapt $h_{X}$ to the desired variety, where $g(\cdot)$ is associated with a nondecreasingreturns-to-scale production function. Then the firm's single plant cost function is

$$
C_{X}\left(w_{L}, w_{H}, x\right)=\min _{h_{X}}\left[w_{L} l\left(x, h_{X}\right)+g\left(w_{L}, w_{H}, h_{X}\right)+w_{H} h_{X}\right] .
$$

This function obviously has the standard properties of cost functions associated with increasing-returns-to-scale production functions. One can also define cost functions for larger numbers of plants. The point worth noting, however, is that the firm or corporation has fixed costs that are corporation specific but not plant specific (they consist of hiring $h_{X}$ and adapting it), it has plant-specific fixed costs, and it has plant-specific variable costs. The assumption that $l(\cdot)$ is the inverse of an increasing-returns-to-scale production function implies that it pays to concentrate production in a single plant unless there are transportation costs or differences across location in product prices. Since impediments to trade are not considered in this paper, the single plant cost function described above is relevant for what follows. All varieties have the same cost structure.

It is assumed that there is Chamberlinian-type monopolistic competition in the differentiated product sector. Hence, as is well known, in this case firms equate marginal revenue to marginal costs and free entry brings about zero profits in every firm. In a symmetrical equilibrium these two conditions can be written as:

$$
p x=C_{X}\left(w_{L}, w_{H}, x\right)
$$

and

$$
R(p, n)=\theta\left(w_{L}, w_{H}, x\right),
$$

where $p$ is the price of every variety of the differentiated product; $R(\cdot)$ is average revenue divided by marginal revenue, and it measures the degree of monopoly power (it is a constant under the Dixit-Stiglitz 
specification of preferences); $n$ is the number of varieties available to consumers; and $\theta(\cdot)$ is average costs divided by marginal costs, using $C_{X}(\cdot)$, and it measures the degree of returns to scale in the production of differentiated products (see Helpman 1981).

The formal conditions of industry equilibrium (1)-(3) that were described above are identical to the conditions used in existing models of trade in differentiated products (see Helpman 1983a). The important difference lies in the interpretation of the technology available to corporations in the differentiated product industry. As in most trade theory I will assume that factors of production do not move across national borders. However, because of the technology available in the differentiated product industry, the firm-specific asset $h_{X}$ can serve product lines in plants that are located in countries other than the country in which $h_{X}$ is located, and the specificity of $h_{X}$ implies that arm's-length trade in its services is an inferior organizational form to an integrated firm (see Klein, Crawford, and Alchian 1978). This is precisely the feature that brings about the emergence of multinational corporations. We will call the country in which $h_{X}$ and the entrepreneurial center are located the parent country of the corporation and the country in which the subsidiary is located the host country.

\section{Equilibrium in an Integrated World Economy}

As a first step toward the study of international trade between economies of the type described in the previous sections, I describe in this section the symmetrical equilibrium of an integrated world economy. The features of the integrated world economy will then be used to identify patterns of cross-country distributions of the world's endowment of labor and the $H$ factor, which generate certain trade patterns and volumes of trade. This particular link provides valuable information because differences in factor endowments can be associated with differences in relative country size and differences in relative factor endowments, two variables that play a major role in empirical studies. We will study trade patterns and volumes of trade for a fixed-size world economy.

In a symmetrical equilibrium of an integrated world economy factor prices are the same everywhere, and all the corporations that operate in the sector that produces differentiated products have a similar structure; every corporation produces one variety, but there is no overlap in varieties produced by two different corporations: they employ the same quantity of the $H$ factor and the same quantity of labor; they charge the same price for every variety and produce the same quantity of each one of them. Free entry into the industry brings 
profits down to zero. The number of corporations $n$ is treated as a continuous variable. This is a reasonable approximation when $n$ is a large number.

Apart from (1)-(3) the equilibrium conditions consist of equilibrium conditions in factor markets and in commodity markets. The equilibrium conditions in commodity markets depend on the specification of preferences, and we will not present them because no use is made of them in what follows (for an example see Helpman 1981). It is only important to remember that the upper tier utility function $u\left(Y, U_{x}\right)$ is homothetic. The equilibrium conditions in factor markets are:

$$
\begin{aligned}
& a_{L Y}\left(w_{L}, w_{H}\right) y+A_{L X}\left(w_{L}, w_{H}, x\right) n=L, \\
& a_{H Y}\left(w_{L}, w_{H}\right) y+A_{H X}\left(w_{L}, w_{H}, x\right) n=H,
\end{aligned}
$$

where $a_{i Y}\left(w_{L}, w_{H}\right)=\partial c_{Y}\left(w_{L}, w_{H}\right) / \partial w_{i}, i=L, H$, is the cost-minimizing input of factor $i$ per unit output of the homogeneous product; $A_{i X}\left(w_{I}\right.$, $\left.w_{H}, x\right)=\partial C_{X}\left(w_{L}, w_{H}, x\right) / \partial w_{i}, i=L, H$, is the cost-minimizing input of factor $i$ in a representative corporation in the differentiated product industry, and $L$ and $H$ are the total quantities of labor and the $H$ factor available. The quantity $A_{H X}(\cdot)$ consists of $h_{X}$ plus any other quantity of $H$ that might be required as an input in the process that converts $h_{X}$ into a firm-specific asset. Condition (4) assures equilibrium in the labor market, and (5) assures equilibrium in the $H$ market. Conditions (1)-(5) plus an equilibrium condition in commodity markets (e.g., that the demand for $Y$ equal its supply) determine the equilibrium values of factor rewards $\left(w_{L}\right.$ and $\left.w_{H}\right)$, the price of differentiated products $(p)$, the output level of a single variety of the differentiated product $(x)$, the output level of the homogeneous good $(y)$, and the number of corporations in the differentiated product industry $(n)$, which equals the number of varieties available to consumers.

For what follows I make the natural assumption that in this equilibrium the homogeneous product is labor intensive relative to the differentiated product; that is,

$$
\frac{a_{L Y}}{a_{H Y}}>\frac{A_{L X}}{A_{H X}} .
$$

Under this assumption the equilibrium distribution of employment across sectors can be described by means of figure 1 . The vector $\mathbf{O} \overline{\mathbf{E}}$ represents the endowment of factors of production, the vector $\mathbf{O Q}$ represents employment in the differentiated product industry, while $O Q^{\prime}$ represents employment in the homogeneous good industry. The line $B B^{\prime}$ represents an equal factor cost line; its slope equals relative factor rewards. It is tangent to an isoquant of the homogeneous good 


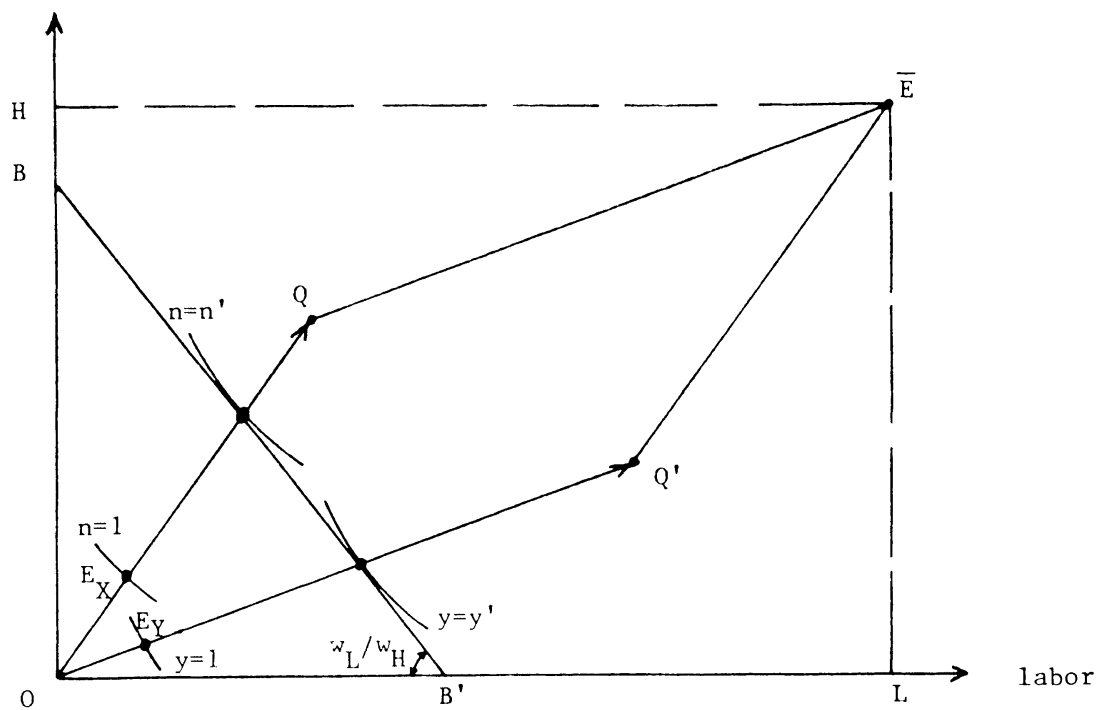

FIG. 1

at its intersection point with $O Q^{\prime}$. At the intersection of $B B^{\prime}$ with $O Q$ the equal factor cost line is also tangent to an isoquant, but one of a different nature. This isoquant can be recovered from the cost function by means of the set $\left\{\left(L_{X}, H_{X}\right) \mid \exists\left(w_{L}, w_{H}\right)>0\right.$ such that $\left(L_{X}, H_{X}\right)=$ $\left.\left[A_{L X}\left(w_{L}, w_{H}, x\right), A_{H X}\left(w_{L}, w_{H}, x\right)\right]\right\}$. This is the collection of inputs that makes possible the production level of a single corporation, and it can be represented by a regularly shaped isoquant, labeled $n=1$ in figure 1. Now draw an entire family of isoquants by a radial expansion and contraction of this single corporation isoquant. Every isoquant in this family represents a different number of corporations, equally sloped on a ray from the origin. Thus, at the intersection of $B B^{\prime}$ with $O Q$ there is an isoquant belonging to this family that is labeled $n=n^{\prime}$. Because of its definition this isoquant is tangent to $B B^{\prime}$.

Finally, observe that using the single corporation isoquant we can calculate the number of corporations that can operate in equilibrium with inputs represented by a point on $O Q$ by dividing the distance of the point from the origin by $\overline{O E}_{X}$. In a similar way the output of the homogeneous good that is obtained in equilibrium by an input combination represented by a point on $O Q^{\prime}$ can be calculated by dividing the distance of the point from the origin by $\overline{O E}_{Y}$. This completes the description of the integrated world equilibrium that is necessary for what follows. 


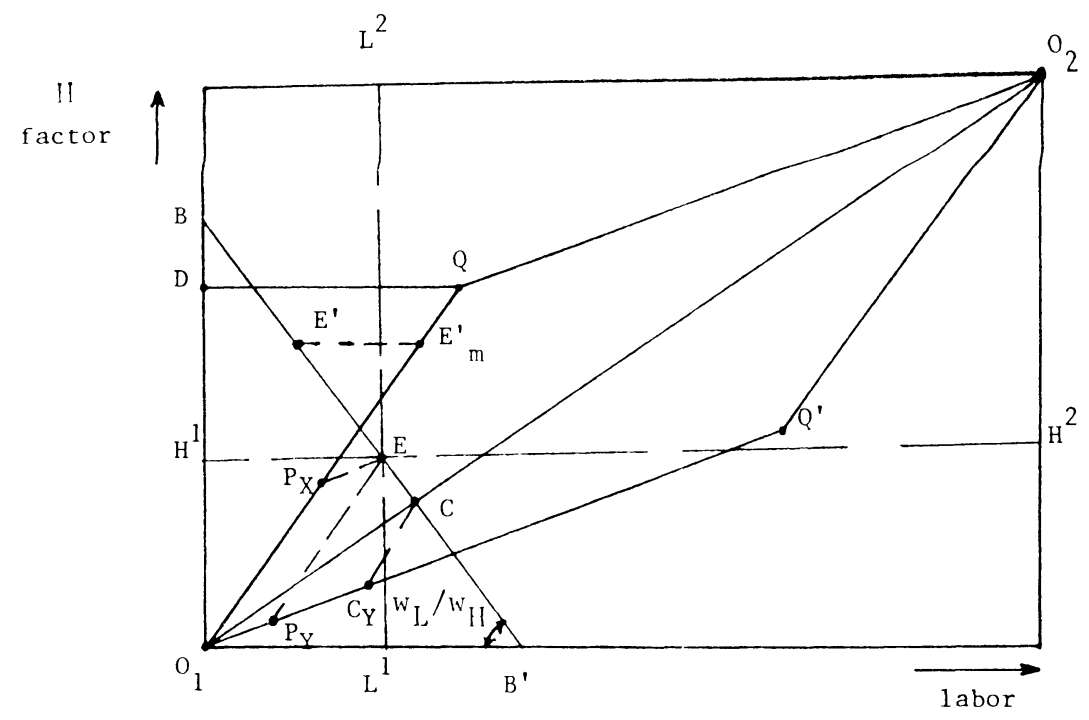

FIG. 2

\section{The Pattern of Trade}

In the standard Heckscher-Ohlin two-country, two-good, two-factor model in which there are no factor intensity reversals and preferences are homothetic and identical across countries, the set of endowment allocations can be divided into two subsets. In the interior of one subset there is factor price equalization and no specialization in production, and every country exports the good whose production makes relatively intensive use of the factor with which the country is relatively well endowed. In the interior of the other subset every country pays a lower reward to the factor of production with which it is relatively well endowed and a higher reward to the other factor of production, at least one country specializes in the production of the good which is a relatively heavy user of its cheaper factor of production, and the pattern of trade is the same as in the former subset. If figure 2 (which is a box-diagram reproduction of fig. 1 with $O_{j}$ representing the origin for country $j$ ) were to describe feasible allocations across countries for a standard Heckscher-Ohlin type economy, then the set with factor price equalization would be represented by $O_{1} Q O_{2} Q^{\prime}$ and the other set by its complement. ${ }^{1}$

\footnotetext{
${ }^{1}$ See Dixit and Norman (1980, chap. 4), who also deal with a case in which there is factor intensity reversal.
} 
The pattern of trade that emerges in the present model is much richer than described above. It is useful to describe it by starting with intercountry factor allocations in the set $O_{1} Q O_{2} Q^{\prime}$ of figure 2. Because of the symmetry in structure it is sufficient to analyze endowment points above the diagonal $\mathrm{O}_{1} \mathrm{O}_{2}$; this way country 1 is the $\mathrm{H}$-factor-rich country while country 2 is the labor-rich country. Allocations in this set were analyzed in Helpman (1981).

Take, for example, the factor endowment point $E$ in figure 2. This point describes an allocation $\left(L^{1}, H^{1}\right)$ of labor and the $H$ factor to country 1 and an allocation $\left(L^{2}, H^{2}\right)$ of labor and the $H$ factor to country 2. It is straightforward to see that with this world structure there is an equilibrium with factor price equalization whose crosscountry aggregation looks the same as the integrated world equilibrium described in the previous section. In this equilibrium corporations based in one country have no incentive to open subsidiaries in the other country in order to locate product lines there. Assuming that under these circumstances all operations of a corporation are concentrated in the parent country, the output level of the homogeneous product in country $j$ and the number of corporations in the differentiated product industry in that country can be solved from the following factor market equilibrium conditions:

$$
\begin{aligned}
a_{L Y} y^{j}+A_{L X} n^{j} & =L^{j}, \\
a_{H Y} y^{j}+A_{H X} n^{j} & =H^{j} .
\end{aligned}
$$

Here the input-output coefficients in the homogeneous product sector and labor and $H$-factor use per corporation in the differentiated product industry are taken from the equilibrium of the integrated world economy, because factor prices, product prices, and output per variety are the same in both cases. This is indeed an equilibrium if the solution of $\left(y^{j}, n^{j}\right)$ from (6)-(7) is nonnegative for $j=1,2$. But this is, of course, the case for every point in $O_{1} Q O_{2}$, as is demonstrated by the broken-line parallelogram drawn from the particular $E$ in figure 2 .

Now observe that because profits are zero all income is factor income. Hence, by drawing through $E$ a line $B B^{\prime}$ whose slope is $w_{I} / w_{H}$, we show the cross-country income distribution. Relative incomes can be read off as follows: Let $C$ be the intersection point of $B B^{\prime}$ with the diagonal $O_{1} O_{2}$. Then the relative income of country 1 is $\overline{O_{1} C}$ divided by $\overline{\mathrm{CO}_{2}}$. In fact, by a proper choice of units, $\overline{\mathrm{O}_{1} \mathrm{C}}$ represents the income level of country 1 and $\overline{\mathrm{CO}_{2}}$ represents the income level of country 2 . Since both countries have the same spending pattern, country 1 consumes a proportion $s^{1}$ of the world's output $y$, where $s^{1}$ is its share in world income. Hence with a line through $C$ parallel to $O_{1} Q$ its comsumption of the homogeneous product can be represented by $\overline{O_{1} C_{Y}}$, 
where $C_{Y}$ is the intersection point of this line with $O_{1} Q^{\prime}$. Since production $y^{1}$ is represented by $\overline{O_{1} P_{Y}}$, country 1 imports the homogeneous product. Finally, since trade is balanced, this means that country 1 is a net exporter of differentiated products.

I have shown that in the set of factor allocations $O_{1} Q O_{2}$ the intersectoral pattern of trade is the same as in the Heckscher-Ohlin model. Here, however, there is also intra-industry trade in differentiated products. Country $j$ produces $n^{j}$ varieties of the differentiated product and it exports them to its trading partner. Hence, the pattern of trade that emerges is the same as in the models of trade in differentiated products that were developed in recent years. To summarize, for factor endowments in the set $O_{1} Q O_{2}$ free trade generates no incentive for the formation of multinational corporations. The structure of trade is the same as in recent models of trade in differentiated products; the intersectoral trade pattern is explained by differences in relative factor endowments while intra-industry trade is explained by monopolistic competition in differentiated products.

The theory proposed in this paper takes on interest because it can identify and analyze the implications of circumstances in which corporations find it profitable to establish subsidiaries abroad. This theory associates multinational corporations with the ability of firms to exploit cross-country differences in factor prices by shifting activities to the cheapest locations. Generally speaking, this theory can be applied to differences in factor prices that result from many different sources. However, in what follows it is applied to potential differences in factor rewards that arise from differences in relative factor endowments.

It is clear from conventional theory and from the previous discussion that factor endowment points above $O_{1} Q O_{2}$ lead to unequal factor prices if firms have to employ all factor inputs in the same country. Suppose that under these circumstances the $H$ factor is cheaper in country 1 and labor is cheaper in country 2. Now consider what happens when a corporation need not employ all labor and $H$ at a single location; for simplicity also assume that no labor is used in the process that adapts $h_{X}$ to the particular variety produced by the corporation. Clearly, under these circumstances corporations wish to choose country 1 as their parent country and they wish to open subsidiaries in country 2. These desires reduce the demand for labor in country 1 and increase it in country 2 , and they increase the demand for the $H$ factor in country 1 and reduce it in country 2. An equilibrium is attained when either factor prices are equalized or country 1 becomes the parent country of all corporations (with unequal factor prices all $H$ producing differentiated products are located in the $\mathrm{H}$ cheap country). When factor price equalization obtains, there are many equilibrium configurations with various degrees of foreign in- 
volvement of the corporations in the differentiated product industry, just as there are many configurations in the factor price equalization set $O_{1} Q O_{2}$. In the latter case, factor price equalization is achieved without invoking the possibility that corporations can decentralize their activities geographically. In the case under current examination factor price equalization can be achieved because companies can decentralize their activities geographically. There are many ways in which the decentralization can be made consistent with equilibrium. The rule to be adopted below is to consider equilibria in which foreign labor employment is as small as possible, which amounts to considering equilibria with the smallest number of multinational corporations. ${ }^{2}$

Start by considering factor allocations that are in the set $O_{1} D Q$ of figure 2. I argue that endowment points in this set lead to equilibria with factor price equalization and the emergence of multinational corporations (I maintain in the figure the assumption that labor is not used in the adaptation process). Clearly, for endowment points in this set there are no equilibria in which factor prices are equalized, and every firm employs its factors of production in a single location. Hence, multinational corporations have to emerge. The only question that remains, therefore, is whether their emergence brings about factor price equalization. Take, for example, the endowment point $E^{\prime}$ in figure 2 . If all the resources of country 1 are employed in the production of differentiated products and its corporations employ in the foreign country the amount of labor $\overline{E^{\prime} E_{m}^{\prime}}$, where $E_{m}^{\prime}$ is the intersection point with $O_{1} Q$ of a horizontal line drawn through $E^{\prime}$, then the aggregate world equilibrium corresponds to the equilibrium of the integrated world economy. In this discussion $E^{\prime}$ is the endowment point and $E_{m}^{\prime}$ is the employment point. The existence of international corporations enables the employment point to differ from the endowment point. The distance $\overline{O_{1} E_{m}^{\prime}}$ represents the number of corporations that are based in country $1\left(n^{1}\right)$ and the distance $\overline{E_{m}^{\prime} Q}$ represents the number of corporations that are based in country $2\left(n^{2}\right)$ (the total number is the same as in the integrated world equilibrium). More precisely, since $y^{1}=0$ and $y^{2}=y$, the number of corporations that are based in country $j, n^{j}$, and the employment of labor in country 2 by subsidiaries of country 1 -based multinationals, $L^{f}$, are obtained from the following factor market clearing conditions:

$$
\begin{gathered}
A_{L X} n^{1}=L^{1}+L^{f}, \quad a_{I, Y} y+A_{L X} n^{2}=L^{2}-L^{f}, \\
A_{H X} n^{1}=H^{1}, \quad a_{H Y} y+A_{H X} n^{2}=H^{2} .
\end{gathered}
$$

\footnotetext{
${ }^{2}$ This choice can be justified as a long-run equilibrium of a dynamic adjustment process in which it is costly to shift plants abroad.
} 
However, the number of varieties produced in country $j$ does not equal $n^{j}$; the number of varieties produced in country 1 is smaller than $n^{1}$ and the number of varieties produced in country 2 is larger than $n^{2}$. The precise difference depends on the size of the labor force $L^{f}$ employed by subsidiaries. In fact the number of varieties produced in country $j, M^{j}, j=1,2$, is

$$
M^{1}=n^{1}-\frac{L^{f}}{A_{L X}}, \quad M^{2}=n^{2}+\frac{L^{f}}{A_{L X}} .
$$

To summarize, we have seen that endowment points in the set $O_{1} D Q$ lead to an equilibrium with factor price equalization and the emergence of multinational corporations. Under my assumption about locational tendencies of corporations, in this set country 1 specializes in the production of differentiated products and it serves as a base for the multinational corporations. Country 1 imports the homogeneous product, and there is intra-industry trade in differentiated products. Part of the intra-industry trade is carried out by multinationals. It is also easy to see that the set $O_{1} D Q$ can be divided into two subsets such that in one subset country 1 is a net exporter of differentiated products and in the other subset country 1 is a net importer of differentiated products. Finally, there exists intrafirm trade whose nature is discussed below.

The existence of intrafirm trade is, of course, well documented in the empirical literature (see, e.g., U.S. Tariff Commission 1973, chap. 2; Buckley and Pearce 1979). This takes the form of imports of the parent firm from its subsidiaries as well as exports of the parent firm to its subsidiaries. Much of this trade stems from vertical integration with which one cannot deal satisfactorily by means of the framework employed in this study, but which can be dealt with in a proper extension (see Helpman 1983b). However, there is one genuine component of intrafirm trade that is well represented by this model, namely, the invisible exports of the parent to its subsidiaries of services of the $H$ input. Observe that because of the zero-profit condition (2) labor costs are lower than the revenue obtained from sales. This means that the multinational corporation is making "profits" in its subsidiary, because the subsidiary hires labor only in the host country. This means that the profits of the subsidiary are just sufficient to cover the costs of the $H$ input, which is hired in the parent country. The difference between revenue and labor costs of all subsidiaries is $\mu p x-w_{L} L^{f}$, where $\mu=L^{f} / A_{L X}$ is the number of multinational corporations. This can be considered to be either profits repatriated by the parent firms or payments by the subsidiaries for services rendered by the parent firms. From an economic point of view the second interpretation is the appropriate one. Hence, $\mu p x-w_{L} L^{f}$ represents intrafirm trade. In order to proceed with the analysis of trade patterns figure 3 


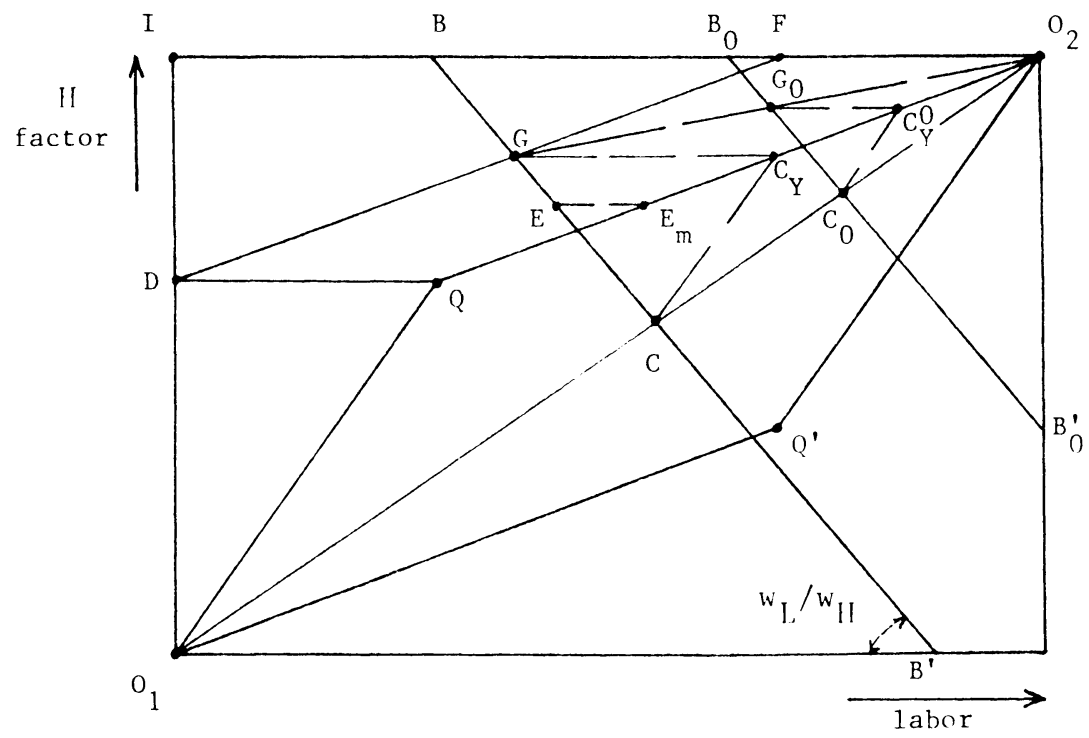

FIG. 3

reproduces the basic features of figure 2 and contains a further division of the set above $O_{1} Q O_{2}$. Now consider endowment points in the parallelogram $\mathrm{O}_{2} Q D F$. Following the discussion of endowment points in the set $O_{1} D Q$ it is clear that endowment points in $O_{2} Q D F$ lead to equilibria with factor price equalization and multinational corporations that are homomorphic to the integrated world economy equilibrium. Thus, if $E$ is the endowment point, then $E_{m}$ is a feasible employment point when the techniques of production of the integrated world equilibrium are used, and $\overline{E E_{m}}$ represents labor employment of country 1-based multinationals in country 2. It is also clear from figure 3 that endowment points in the set DIF can have no equilibria with factor price equalization, for in order to use the integrated world equilibrium production techniques country 1 has to employ in country 2 a quantity of labor larger than total employment required in the differentiated product industry. This cannot take place, because only in this sector can corporations shift activities to other countries. Hence, for endowment points in the set $D I F$, all corporations that produce differentiated products are based in country 1 and all product lines are located in country $2{ }^{3}$ Country 1 exports services of the $H$ input and imports all the differentiated products from country 2. It may import or export the homogeneous product.

\footnotetext{
${ }^{3}$ This is necessarily so when production is homothetic. It seems that the reverse pattern of specialization is possible in the absence of homotheticity.
} 
Returning to endowment points in the set $\mathrm{O}_{2} Q D F$, observe that there are two possible patterns of trade depending on the location of the endowment point. For the endowment point $E$ and the employment point $E_{m}$, country 1 imports the homogeneous product as well as varieties of the differentiated product that are produced by its subsidiaries, and it exports the other varieties as well as services of the $H$ input. The only part of this assertion that requires elaboration is that country 1 imports the homogeneous product. This can be seen as follows. Let $B B^{\prime}$ be the equal cost line that passes through $E$. Then its intersection point with the diagonal $O_{1} O_{2}$, that is, point $C$, represents each country's income level. Draw through $C$ a line parallel to $O_{1} Q$ and let $C_{Y}$ be its intersection point with $O_{2} Q$. Then $\overline{O_{2} C_{Y}}$ represents the consumption level of the homogeneous product in country 2 while $\overline{\mathrm{O}_{2} E_{m}}$ represents the output level of the homogeneous product in country 2. Hence, country 2 exports the homogeneous product and country 1 imports it. It is clear from figure 3 that the same pattern of trade emerges for all endowment points on $B B^{\prime}$ that belong to $O_{2} Q D F$.

Now consider endowment points in $O_{2} Q D F$ that lie on $B_{0} B_{0}^{\prime}$. For the distribution of income represented by this line the consumption of the homogeneous product is represented by $\overline{O_{2} C_{Y}^{0}}$ (constructed in the same way as above). It is clear, however, that only at endowment points below $G_{0}$ does country 2 export the homogeneous product, while at endowment points above $G_{0}$ country 1 exports the homogeneous product. At point $G_{0}$ (as well as at point $G$ ) there is no trade in the homogeneous product. Generally, at endowment points that are in $O_{2} Q D F$ but below $G_{2}$, the pattern of trade is as the one described for point $E$. On the other hand, at endowment points that belong to $\mathrm{O}_{2} Q D F$ but are above $\mathrm{GO}_{2}$, country 1 exports the homogeneous product as well as services of the $H$ input and some varieties, while country 2 exports only varieties that are produced by subsidiaries of country 1-based multinationals. A further division into subsets in which country 1 is a net exporter or a net importer of differentiated products is also possible.

We have identified five sets of endowment distributions relevant for the study of trade patterns $\left(O_{1} Q O_{2}, O_{1} D Q, O_{2} Q D G, O_{2} G F\right.$, and $\left.D I F\right)$. In four of them the equilibrium requires the existence of multinational corporations. Overall, they represent a rich collection of trade patterns with features that seem to fit reality better than those provided by existing trade theories.

\section{The Volume of Trade}

I have described in the previous section possible trade patterns and how they are related to the distribution of the world's endowment of 


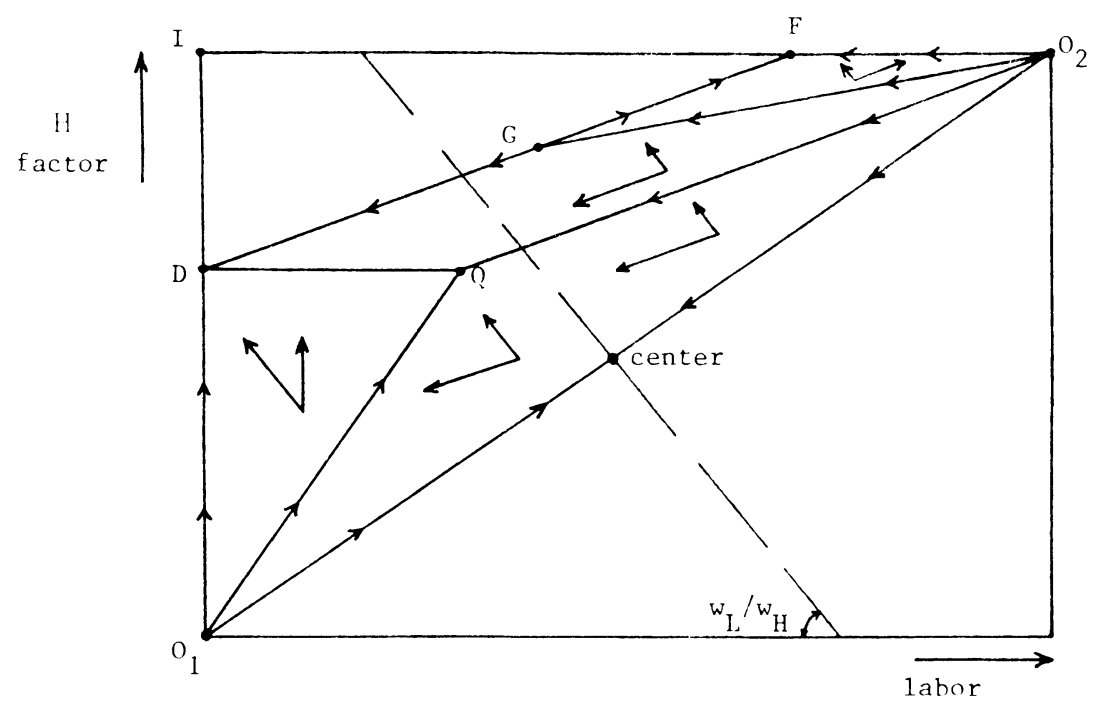

Fig. 4

factors of production. As is clear from the partition of the endowment set into subsets in which certain patterns of trade obtain (see fig. $3)$, the pattern of trade depends on two factors: $(a)$ relative country size in terms of GNP and $(b)$ the difference in relative factor endowments. For example, if country 1 is relatively small and has a relatively high endowment of the $H$ factor, then the endowment point is in $O_{1} D Q$, there exist multinational corporations that are based in country 1 , country 1 exports differentiated products and invisible $H$ services to its subsidiaries, and it imports differentiated products and the homogeneous good. Differences in relative factor endowments and the relative sizes of the countries are observable economic variables of major interest. I provide, therefore, in this section a description of the effects that these two variables have on the volume of trade. These findings are summarized by figure 4 in which the arrows indicate directions in which the volume of trade increases.

Start by considering endowment points in the set $O_{1} Q O_{2}$. In this region there are no multinational corporations. The volume of trade is defined in the usual way as the sum of exports, where the summation is over countries and sectors. Because of balanced trade, this is equal in a two-country world to twice the exports of one of the countries. In this set country 1 exports only differentiated products, so that the volume of trade is:

$$
V=2 p x s^{2} M^{1} \quad \text { for } E \in O_{1} Q O_{2},
$$


where $M^{1}$ is the number of varieties produced in country 1 and $s^{2}$ is the share of country 2 in world income. Hence, for fixed relative country size the volume of trade increases with the number of varieties produced in the $H$-factor-rich country, and for a fixed number of varieties produced in country 1 the volume of trade increases with the relative size of country 2 . Since $M^{1}$ is fixed on lines parallel to $O_{2} Q$, the arrows inside the set $O_{1} Q O_{2}$ and on $O_{2} Q$ in figure 4 describe directions in which the volume of trade increases.

On the diagonal $O_{1} O_{2}$ we have $M^{1}=s^{1} M$, where $M=n$ is the number of varieties produced in the world economy. Upon substitution into (10a) this yields:

$$
V=2 p x M s^{1} s^{2} \text { for } E \in O_{1} O_{2},
$$

implying that the volume of trade is largest when the countries are of equal size and is smaller the more unequal the size of countries. This is also described by the arrows in figure 4 .

On the line $O_{1} Q$ we have $p x M^{1}=s^{1} Z$, where $Z$ is world income and spending and $M^{1}=n^{1}$. Hence, upon substitution into (10a):

$$
V=2 Z s^{1} s^{2} \text { for } E \in O_{1} Q
$$

and the volume of trade rises the more equitable is the world's distribution of income. In figure 4 country 1 is of smaller size than country 2 at endowment points on $O_{1} Q$ (which is, of course, not always the case); therefore the volume of trade increases in the northeastern direction as indicated by the arrow. The behavior of the volume of trade in the set $O_{1} Q O_{2}$ described above is a generalization of propositions 5 and 6 in Helpman (1981).

For endowment points in $O_{1} D Q$ country 2 exports the homogeneous good and $M^{2}$ varieties of the differentiated product. Some of the varieties it exports are produced by country 2 -based firms while $\mu$ of them are produced by subsidiaries of country 1 -based multinational corporations. The same trade pattern exists in $\mathrm{O}_{2} Q D G$, except that in this set all the varieties exported by country 2 are produced by country 1 -based multinationals (i.e., $M^{2}=\mu$ ). This means that the volume of trade can be represented as follows:

$$
V=2\left(y^{2}-Y^{2}+p x s^{1} M^{2}\right) \text { for } E \in\left(O_{1} D Q\right) \cup\left(O_{2} Q D G\right) .
$$

For endowment points in $O_{1} D Q$ the homogeneous product is produced only in country 2 , so that $y^{2}=y$. Also, since $Y^{2}=s^{2} y=(1-$ $\left.s^{1}\right) y$, upon substitution into (11) we obtain:

$$
V=2 s^{1}\left(y+p x M^{2}\right) \text { for } E \in O_{1} D Q .
$$

This means that when the relative country size is given the volume of trade increases with the number of varieties produced in country 2 , 
whereas when the number of varieties produced in country 2 is given, the volume of trade increases with the relative size of country 1 , as shown in figure 4.

At endowment points in the set $O_{2} Q D G$ all the varieties exported by country 2 are produced by subsidiaries of country 1 -based multinationals; that is, $M^{2}=\mu$. Also $Y^{2}=s^{2} y$ and $s^{2} Z=y^{2}+w_{L} \mu A_{L X}$, where $Z$ $=p x n+y$. Combining these with (11), we obtain:

$$
V=2\left[\left(1-s^{1}\right) p x n+p x \mu\left(s^{1}-\theta_{L X X}\right)\right] \text { for } E \in O_{2} Q D G,
$$

where $\theta_{L X X}$ is the share of labor costs in the production of differentiated products. Hence, when the relative country size is given the volume of trade increases with the widening of the difference in relative factor endowments (with $\mu$ ) if and only if the share of country 1 in world income exceeds the share of labor costs in the differentiated product industry. The arrows in $\mathrm{O}_{2} Q D G$ that indicate the increase in the volume of trade in the northwestern direction (see fig. 4) are drawn on the assumption $s^{1}>\theta_{L X X}$ (which always holds for endowment points close to $\mathrm{O}_{2}$ ). It is also clear from (13a) that given $\mu$ the volume of trade decreases as the relative size of country 1 increases. However, $\mu$ is constant on lines parallel to $\mathrm{O}_{2} Q$. Therefore, the volume of trade increases in the southwestern direction as indicated by the arrows drawn in region $O_{2} Q D G$ and on $D G$. Finally, on $O_{2} G$ we have $M^{2}=\mu, y^{2}=Y^{2}=s^{2} y$, and $s^{2} Z=y^{2}+w_{L} \mu A_{L X X}$, which yield upon substitution into (11):

$$
V=\frac{2 s^{1} s^{2} p x(Z-y)}{w_{1} A_{L X}} \quad \text { for } E \in O_{2} G,
$$

implying that the volume of trade declines the more unequal countries are in relative size. This is indicated by the arrows drawn on $O_{2} G$.

It remains to consider endowments in $\mathrm{O}_{2} G F$. In this region country 2 exports only differentiated products produced by subsidiaries of country 1 -based multinationals, and the volume of trade is

$$
V=2 p x s^{1} \mu \text { for } E \in O_{2} G F
$$

implying that for given $\mu$ the volume of trade rises with the relative size of country 1 and that for given relative country size it rises with $\mu$. On $\mathrm{O}_{2} \mathrm{~F} \mu$ is proportional to $s^{2}$, which makes the volume of trade larger the closer the endowment is to $F$ (because on $\mathrm{O}_{2} F, s^{1}>s^{2}$ ). These features are also represented by arrows in figure 4 .

In summary, figure 4 represents a fairly detailed description of the relationship between factor endowments and the volume of trade. It shows that in some sense the larger the difference in relative factor endowments the larger is the volume of trade. On the other hand, relative country size has an ambiguous effect on the volume of trade. 


\section{Intra-Industry and Intrafirm Trade}

In this section I investigate the dependence of the shares of intraindustry and intrafirm trade on cross-country differences in relative factor endowments. In all cases, except for region $O_{1} Q O_{2}$, the investigation is restricted to fixed relative sizes of the two countries.

The volume of intra-industry trade is defined as the total volume of trade minus the sum over all sectors of the absolute value of the difference between imports and exports. In the current model this reduces to

$$
V_{i-i}=2 p x \min \left(s^{1} M^{2}, s^{2} M^{1}\right) .
$$

The definition of the volume of intrafirm trade is more complicated. Exports of the parent firms of services of the $H$ factor are undoubtedly part of this volume of trade. The problem arises with the treatment of the finished differentiated products. If parent firms serve as importers of the finished products manufactured by their subsidiaries, then this appears in the data as intrafirm trade, and similarly if subsidiaries serve as importers of the differentiated products manufactured by parent firms. In some cases the treatment of these flows of goods as intrafirm trade has no economic justification because it is more the consequence of bookkeeping practices than a true economic calculus. In the present model there is no natural choice-much depends on the implicit assumptions about the marketing technology. I choose, therefore, to define intrafirm trade as trade in the services of the $H$ factor. Hence,

$$
V_{i-1}=p x \mu-w_{L} L^{\prime}=a \mu,
$$

where $a=w_{I I} A_{I X}>0$.

For endowment points in $O_{1} Q O_{2}$ we have $s^{1} M^{2}<s^{2} M^{1}$, so that using (10a) and (15) we calculate the share of intra-industry trade to be

$$
S_{i-i}=\frac{s^{1} M^{2}}{s^{2} M^{1}}=\frac{s^{1} n^{2}}{s^{2} n^{1}} \text { for } E \in O_{1} Q O_{2} .
$$

This is shown in Helpman (1981, proposition 4) to be a declining function of the difference in relative factor endowments. The share of intrafirm trade is zero at endowment points that belong to $O_{1} Q O_{2}$ because in this region there are no multinational corporations.

Using (12), we obtain:

$$
S_{i-i}=\frac{p x \min \left(s^{1} M^{2}, s^{2} M^{1}\right)}{s^{1}\left(y+p x M^{2}\right)} \text { for } E \in O_{1} D Q .
$$

Since one can show that $M^{1} / M^{2}>s^{1} / s^{2}$ on $O_{1} Q$, then for a given relative country size the share of intra-industry trade rises with the difference 
in relative factor endowments as we start moving the endowment allocation along an equal income line from a point on $O_{1} Q$ in the northwestern direction. If country 1 is small enough, however, this share reaches a maximum and declines with further redistributions that increase the gap in relative factor endowments. This means that with the emergence of multinational corporations the share of intraindustry trade may be positively or negatively related to differences in relative factor endowments. Using (16), the share of intrafirm trade in $O_{1} D Q$ can be represented by

$$
S_{i-f}=\frac{a(\mu / 2)}{s^{2} p x M^{1}+a \mu} \text { for } E \in O_{1} D Q
$$

where $s^{2} p x M^{1}+a \mu$ is the volume of exports from country 1 . Therefore, for given relative country size a widening of the difference in the $H$ to $L$ ratio between country 1 and country 2 increases the share of intrafirm trade (because it increases $\mu$ and reduces $M^{1}$ ).

For an endowment point in $O_{2} Q D G$ we have $M^{2}=\mu$, so that (15), (16), and (13a) imply:

$$
\begin{array}{cc}
S_{i-i}=\frac{p x \min \left(s^{1} \mu, s^{2} M^{1}\right)}{\left(1-s^{1}\right) p x M+p x \mu\left(s^{1}-\theta_{L X X}\right)} & \text { for } E \in O_{2} Q D G, \\
S_{i-f}=\frac{a(\mu / 2)}{\left(1-s^{1}\right) p x M+p x \mu\left(s^{1}-\theta_{L X X}\right)} & \text { for } E \in O_{2} Q D G .
\end{array}
$$

Assume $s^{1}>\theta_{L X X}$ in this region. Then, for a given relative country size, starting from $\mathrm{O}_{2} Q$ the share of intra-industry trade rises with increases in the difference between the $H$ to $L$ ratio in country 1 and country 2 , and it may reach a maximum and decline afterward. This pattern is similar to that in $O_{1} D Q$. The share of intrafirm trade, on the other hand, is larger the larger the difference in relative factor endowments (given relative country size).

In region $\mathrm{O}_{2} G F$ country 2 exports only differentiated products. Therefore, because of balanced trade, at endowment points that belong to it $s^{1} \mu>s^{2} M^{1}$. Using this relationship as well as (14), (15), and (16), we find that on lines in $\mathrm{O}_{2} G F$ that represent constant relative country size, the share of intra-industry trade declines with increasing differences in relative factor endowments and the share of intrafirm trade is constant.

The broad picture that emerges from this analysis is that for given relative country size the share of intrafirm trade is larger the larger the difference in relative factor endowments, but that in the presence of multinational corporations no clear-cut relationship exists between the share of intra-industry trade and differences in relative factor endowments. 


\section{Concluding Comments}

I have developed in this paper a general equilibrium theory of international trade in which multinational corporations play an essential role. This theory can identify and analvze the implications of circumstances in which corporations find it profitable to become multinational. These corporations are well-defined economic entities, they possess firm-specific assets, they engage in monopolistic competition, and they play an active role in foreign trade. The theory explains the simultaneous existence of intersectoral trade, intra-industry trade, and intrafirm trade. Despite the relative richness of the theory it needs further extensions and elaborations in order to deal with the wide range of problems that are at the heart of international economics. An extension of the current theory to horizontally as well as vertically integrated corporations is presented in Helpman (1983b). This extension generates more realistic patterns of resource allocation without altering the fundamental properties of trade patterns that were derived in the current study. In particular, integrated multinational corporations end up having production facilities in parent as well as in host countries, and the existence of vertical integration brings about intrafirm trade both in $H$ services and in intermediate inputs. This realism is achieved at a substantial cost in terms of the complexity of the theory of the firm. Nevertheless, I believe the benefit-cost ratio to be larger than one. The current theory can also explain cross-country penetration of multinational corporations as a result of impediments to trade (such as transport costs or tariffs). This is evident from the fact that the establishment of a new plant for the same variety requires additional fixed costs but saves the costs associated with trade impediments and does not require the hiring of new $H$ factors. Hence, for sufficiently high impediments, cross-country penetration is expected.

\section{References}

$\rightarrow$ Buckley, Peter J., and Pearce, Robert D. "Overseas Production and Exporting by the World's Largest Enterprises: A Study in Sourcing Policy." J. Internat. Bus. Studies 10) (Spring/Summer 1979): 9-20.

Caves, Richard E. "International Corporations: The Industrial Economics of Foreign Investment." Economica 38 (February 1971): 1-27.

- Multinational Enterprise and Economic Analysis. Cambridge: Cambridge Univ. Press, 1982.

Dixit, Avinash K., and Norman, Victor. Theory of International Trade. Cambridge: Cambridge Univ. Press, 1980.

Dixit, Avinash K., and Stiglitz, Joseph E. "Monopolistic Competition and Optimum Product Diversity." A.E.R. 67 (September 1977): 297-308.

$\rightarrow$ Helpman, Elhanan. "International Trade in the Presence of Product Differentiation, Economies of Scale and Monopolistic Competition: A Chamber- 
lin-Heckscher-Ohlin Approach." J. Internat. Econ. 11 (August 1981): 30540 .

. "Increasing Returns, Imperfect Markets, and Trade Theory." In Handbook of International Economics, vol. 1, edited by Ronald W. Jones and Peter B. Kenen. Amsterdam: North-Holland, 1983. (a)

. "Multinational Corporations and Trade Structure." Mimeographed. Cambridge, Mass.: M.I.T., December 1983. (b)

$\rightarrow$ Hirsch, Seev. "An International Trade and Investment Theory of the Firm." Oxford Econ. Papers 28 (July 1976): 258-70.

$\rightarrow$ Klein, Benjamin; Crawford, Robert G.; and Alchian, Armen A. "Vertical Integration, Appropriable Rents, and the Competitive Contracting Process." J. Law and Econ. 21 (October 1978): 297-326.

Lancaster, Kelvin. Variety, Equity, and Efficiency. New York: Columbia Univ. Press, 1979.

U.S. Tariff Commission. Implications of Multinational Firms for World Trade and Investment and for U.S. Trade and Labor. Washington: Government Printing Office, 1973.

$\rightarrow$ Williamson, Oliver E. "The Modern Corporation: Origins, Evolution, Attributes." J. Econ. Literature 19 (December 1981): 1537-68. 